\title{
The Kungälv Conference
}

By Sune Akerman

This issue of our periodical contains a detailed report of the NAAS conference held during the Summer of 1971 in Kungäly, Sweden. There is no need to comment on the program of the conference but rather simply state that there is evidently a growing interest among the Nordic countries to engage in NAAS' activities. At the conference, which also functioned as the yearly meeting for NAAS, it was decided to undertake certain organizational changes. It was decided that successive changes should occur within the executive committee, resulting in a younger and more vital committee. Furthermore it was decided that the committee should be strengthened by the addition of a delegate from each country. Also local committees will be organized to work on a national level. We hope, for example, to arrange smaller and less ambitious conferences in each of the Nordic countries.

The new delegates to the executive committee are as follows: Dr. Jóhann S. Hannesson, Iceland; Dr. Brita Lindberg-Seyersted, American Institute, Oslo; Dr. Merete Licht, Dept. of English, Univ. of Copenhagen; Dr. Hans Aldskogius, Dept. of Geography, Univ. of Uppsala, Sweden; Prof. Nils Erik Enkvist, Dept. of English, Univ. of Åbo, Finland. At the conference it was also decided that a special editorial committee be created to assist the editorial staff. The reason for the creation of this committee is to allow a better coverage of Nordic research within the field of American studies. The members of the editorial committee are as follows: Dr. Kristian Hvidt, head of Library of Parliament, Copenhagen; Dr. Orm Øverland, Univ. of Bergen, Norway; Prof. Olov Fryckstedt, American Institute; Univ. of Uppsala, Sweden; Erik Allardt, head of the Dept. of Sociology, Helsinki, Finland. 
In this issue the introductory lecture of the Kungäly conference, "USA and the Third World", by Prof. Karl Erik Svendsen, Copenhagen, personal advisor of President Nyerere, is presented along with two studies on Theodore Dreiser by Orm Øverland and Rolf Lundén.

We hope that the new concentration on the editorial section will result in a more varied content for this periodical and above all that we will be able to publish more of the research concerning America in the field of social sciences. 